Katarzyna Leśniewska-Napierała

https://orcid.org/0000-0003-2998-6179

Uniwersytet Łódzki

Instytut Zagospodarowania Środowiska i Polityki Przestrzennej

CiTUR, Centrum Badań, Rozwoju i Innowacji w Turystyce, Portugalia

katarzyna.lesniewska@geo.uni.lodz.pl

Tomasz Napierała

https://orcid.org/0000-0002-6407-5197

Uniwersytet Łódzki

Instytut Geografii Miast i Turyzmu

CiTUR, Centrum Badań, Rozwoju i Innowacji w Turystyce, Portugalia tomasz.napierala@geo.uni.lodz.pl

Kathleen M.C. Tjørve

https://orcid.org/0000-0002-7514-838X

\title{
Even Tjørve
}

https://orcid.org/0000-0001-8822-2094

Uniwersytet Nauk Stosowanych Środkowej Norwegii

Instytut Turystyki, Przemysłów Kreatywnych i Marketingu

kathy.tjorve@inn.no, even.tjorve@inn.no

\section{KONKURS JAKO METODA PEDAGOGICZNA W TURYSTYCZNEJ EDUKACJI UNIWERSYTECKIEJ: STUDIUM PRZYPADKU NAUCZANIA TWÓRCZEGO ROZWIAZZYWANIA PROBLEMÓW ${ }^{1}$}

\begin{abstract}
Abstrakt: Głównym celem artykułu jest dyskusja na temat tego, czy możliwość implementacji konkursu jako narzędzia edukacyjnego do rozwijania kreatywności uczestników jest ograniczona, kiedy główną motywację uczestniczących w nim studentów stanowi wygrana. Na potrzeby niniejszego artykułu jako studium przypadku wykorzystano konkurs 24 HOURS. Do oceny efektywności konkursu zastosowano trzy metody: pisemną ankietę, indywidualne wywiady pogłębione oraz ankietę online. Wyniki wykazały, iż konkurs zwiększył kreatywność studentów w stopniu niezadowalającym, ponieważ bardziej byli oni skupieni na wygraniu lub zdobyciu wiedzy niż na współpracy lub interakcji z członkami innych zespołów studenckich. Badanie potwierdziło, że opiekunowie studentów są odpowiedzialni za uruchomienie mechanizmów ukierunkowanych zarówno na współpracę, jak i na kreatywność podczas konkursu. Biorąc jednak pod uwagę, że oczekiwania dotyczące zaangażowania opiekunów stały się źródłem pewnych problemów, rola tych osób powinna zostać ściśle określona. Analiza studium przypadku przedstawiona w tym artykule powinna przyczynić się do lepszego rozumienia przez pedagogów projektowania i wykorzystywania konkursów jako narzędzi edukacyjnych.
\end{abstract}

Słowa kluczowe: turystyka, edukacja uniwersytecka, konkurs.

\section{WSTĘP}

Zainteresowanie turystyczną edukacją uniwersytecką wyraźnie wzrosło w ciągu ostatnich 50 lat. Jest to szczególnie widoczne w kontekście gwałtownie rosnącej innowacyjności za sprawą zastosowania nowych technologii w sektorze turystycznym (Barkathunnisha, Lee,
Price, 2017; Ndou, Mele, Del Vecchio, 2018; Sigala, Baum, 2003). Krytyczne podejście do edukacji turystycznej zmusza studentów do szerszego i głębszego analizowania zagadnień z tego zakresu (Rouzrokh, Muldoon, Torabian, Mair, 2017). Umiejętności i zachowania 
ukierunkowane na kreatywne i krytyczne myślenie stały się priorytetowe na turystycznym rynku pracy (Ndou, Mele, Del Vecchio, 2018). Opracowywanie nowych pomysłów na rozwiązywanie problemów w przemyśle turystycznym powinno zostać wzbogacone o nowe myślenie, wiedzę i doświadczenie opierające się na wykorzystaniu istniejących teorii, opisujących zmieniające się potrzeby turystów (Li, Liu, 2016).

Poszukując innowacyjnych narzędzi edukacyjnych, badacze przede wszystkim koncentrują się na korzyściach płynących z zastosowania nowych metod $\mathrm{w}$ porównaniu $\mathrm{z}$ tradycyjnym uczeniem się w klasie, w kontekście uzyskania efektywniejszego transferu wiedzy. W konsekwencji oczekuje się lepszego zrozumienia przez studentów nowych informacji, które są im przekazywane, i skuteczniejszego ich wykorzystania. Wyraźnie określone cele i poziomy trudności nauczania powinny umożliwić studentom rozwiązywanie coraz bardziej skomplikowanych zadań. Co więcej, powinni oni być dodatkowo motywowani poprzez dającą radość i stanowiącą wyzwanie interakcję z innymi osobami uczącymi się (Paraskeva, Mysirlaki, Papagianni, 2010).

Jak zauważyli Barkathunnisha, Lee, Price (2017), w edukacji turystycznej potrzebne są dociekliwość oraz społeczny system uczenia się, oparty na doświadczaniu i uczestnictwie. Niestety istnieje relatywnie niewiele badań pedagogicznych dotyczących rozwoju metod nauczania innowacyjności i kreatywności. Równie mało studiów tego typu zostało przeprowadzonych nad edukacją przyszłych pracowników przemysłu turystycznego. W niniejszym artykule przedstawiono jedną z technik nauczania, która może być stosowana w uczeniu się i nauczaniu umiejętności społecznych potrzebnych do rozwiązywania problemów w dziedzinie turystyki. Co więcej, technika ta może zwiększyć kreatywność.

Głównym celem artykułu jest omówienie ograniczeń konkursu jako narzędzia służącego rozwijaniu kreatywności uczestników, kiedy główną motywację studentów stanowi wygrana. Ponadto szeroko przedyskutowano, jaką rolę w konkursie odgrywają opiekunowie jako osoby odpowiedzialne za pobudzanie kreatywności. Badania zrealizowano na przykładzie konkursu 24HOURS, aby ocenić skuteczność konkursów jako narzędzi turystycznej edukacji uniwersyteckiej. Zakłada się, że skuteczna metoda edukacyjna rozwija kreatywność studentów głównie poprzez współpracę i nawiązywanie kontaktów, przy wsparciu opiekunów. Skuteczność odnosi się do możliwości stymulowania kreatywności studentów poprzez konkurs, wzbudzenia u nich chęci wygrania go, rozwijania wiedzy i kompetencji społecznych, jak również tworzenia sieci relacji między osobami studiującymi. Uwzględniono tu również wpływ opiekunów grup studenckich na edukacyjną skuteczność konkursów. Zaprezentowana $\mathrm{w}$ artykule analiza studium przypadku może dostarczyć pedagogom wiedzy na temat projektowania i stosowania konkursów jako narzędzi edukacyjnych.

\section{PRZEGLĄD LITERATURY}

\subsection{KONKURS JAKO NARZĘDZIE EDUKACYJNE}

Dagiene i Skupiene (2004) wskazuja, że konkursy są formą nauczania, w której wykorzystywana jest metoda rozwiązywania problemów, w przeciwieństwie do tradycyjnego nauczania w klasie, często skoncentrowanego na małym, konkretnym ćwiczeniu. Pomimo faktu, iż analiza zestawów rzeczywistych danych jest trudniejsza, wielu studentów woli pracować nad nimi niż nad abstrakcyjnymi problemami (Boyle i in., 2012). Zestawy danych opisujących rzeczywistość są dla jednostki często atrakcyjniejsze, bardziej intuicyjne i wywołują jej osobiste zainteresowanie (Dagiene, 2010). W konsekwencji wartość dodana wykorzystywania konkursów jako narzędzi edukacyjnych płynie z pozytywnego nastawienia studentów do pracy nad zagadnieniami praktycznymi. Uczenie się w nawiązaniu do realiów prawdziwego życia jest sugerowane w niektórych najnowszych badaniach (Johnston, Boyle, MacArthur, Manion, 2013) jako zachęcający dodatek do nowoczesnych narzędzi edukacyjnych, które pozwalają studentom rozpoznać, przedyskutować i rozwiązać złożone, wieloaspektowe i faktycznie istniejące problemy poprzez zastosowanie różnych metod.

W dyskusji o grach jako narzędziu edukacyjnym Johnston, Boyle, MacArthur, Manion (2013) twierdza, że takie nowoczesne narzędzia powinny dodatkowo zwiększyć doświadczenie studentów, rozwinąć ich wiedzę oraz pomóc zastosować tę wiedzę i umiejętności w bezpiecznym środowisku, maksymalnie symulującym rzeczywistość. W rezultacie konkurs powinien być narzędziem edukacyjnym, w którego ramach uczenie się wynika z zadania postawionego rywalizującym studentom, opis zadania, które ma być rozwiązane podczas konkursu, pogłębia wiedzę, a umiejętności rozwijane są przez udział w konkursie (Pauschenwein, Goldgruber, Sfiri, 2013).

Prince (2004) założył, że różnica między uczeniem się kolaboratywnym a kooperatywnym polega na metodzie oceny studenta. Obie wspomniane formy uczenia się oznaczają pracę $\mathrm{w}$ grupie $\mathrm{w}$ celu rozwiązania konkretnego problemu, ale w kooperatywnym uczeniu się studenci oceniani są indywidualnie, podczas gdy w kolaboratywnym - jako grupa. 


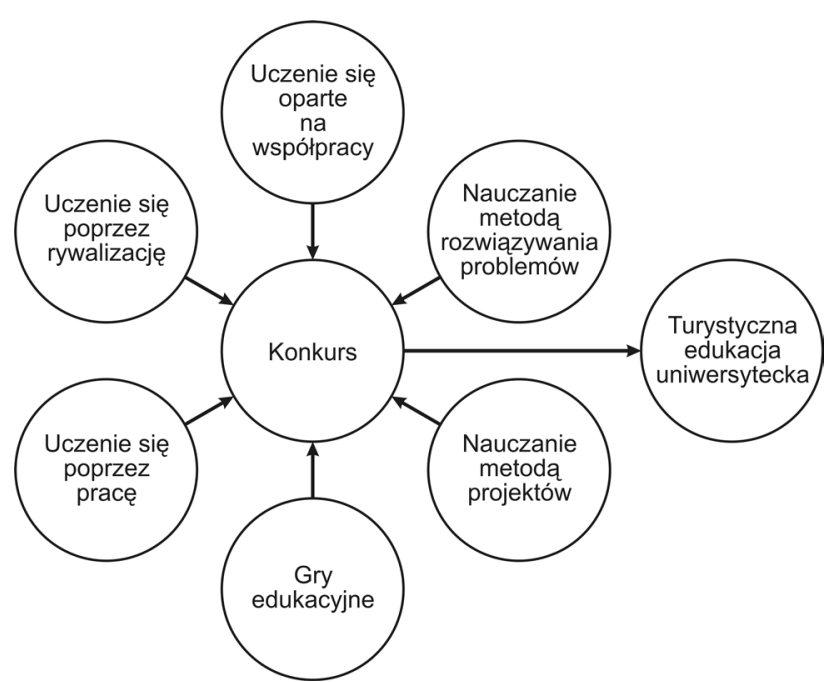

Rysunek 1. Konkurs i inne narzędzia edukacyjne stosowane w turystycznej edukacji uniwersyteckiej Źródło: autorzy

Nauczanie metodą rozwiązywania problemów (ang. problem-based learning) zaczyna się od przedstawienia konkretnego problemu (Prince, 2004). Następnie studenci są motywowani do poznania i przedyskutowania rozwiązania go. Nauczanie metodą rozwiązywania problemów ma zazwyczaj, choć niekoniecznie, charakter kolaboratywny lub kooperatywny. Aspekt rywalizacji $\mathrm{w}$ grupowym rozwiązywaniu problemu jest postrzegany przez Prince’a (2004) jako przeciwieństwo efektów indywidualnej pracy studentów. Na rys. 1 przedstawiono podsumowanie wyżej omówionych charakterystycznych cech konkursu jako narzędzia edukacyjnego.

\subsection{STYMULOWANIE KREATYWNOŚCI STUDENTÓW POPRZEZ KONKURS}

W konkursie czynniki mające wpływ na kreatywność jego uczestników można podzielić na dwie grupy: stosunek studentów do konkursu oraz różnice między studentami w zakresie kreatywności, wiedzy i kompetencji społecznych (rys. 2). Niezależnie od dziedziny studiów kreatywność postrzegana jest jako podstawowy czynnik innowacyjności, która stymuluje nową wiedzę. Kreatywność omawiana w tym artykule definiowana jest za Liangiem i Linem (2015) jako zdolność studenta do wypracowania unikatowego rozwiązania zadania w konkursie, spełniającego kryteria zarówno oryginalności, jak i aplikacyjności. Zdolność poznawcza (uczenie się, które pozwala na rozumienie istniejącej wiedzy, np. wyobraźnia reproduktywna) i kreatywność (rozwijanie nowej wiedzy) są wynikiem wyobraźni produktywnej (Liang, Lin, 2015).

Skuteczna współpraca studentów zależy od efektywności relacji zbudowanych między nimi. Potrze-

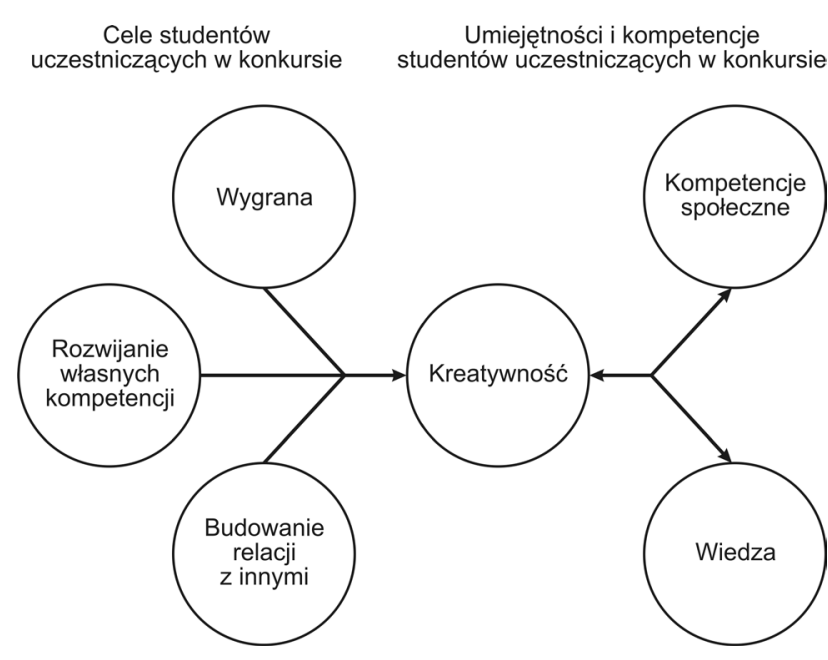

Rysunek 2. Kreatywność a umiejętności i kompetencje studentów oraz ich postawy podczas konkursu Źródło: autorzy

bują oni zatem zarówno umiejętności społecznych, jak i poznawczych w uczeniu się kooperatywnym. Kompetencje społeczne są rozumiane jako zdolność do zażegnywania konfliktów i zarządzania rywalizacją pojawiającą się w grupie, a w odniesieniu do członków grupy - do bycia otwartym na inne punkty widzenia. Zdolności poznawcze pozwalają studentom wykorzystywać, nabywać, a nawet tworzyć wiedzę. Odnoszą się one zatem do umiejętności stawiania pytań, definiowania problemów, formułowania hipotez, określania celów oraz wykorzystywania narzędzi i metod w poszukiwaniu rozwiązań (Cohen, 1994). Konkurs może być postrzegany jako nieformalne narzędzie do przedstawienia określonego tematu grupie studentów. Konkursy uatrakcyjniają proces uczenia się i potencjalnie czynią go bardziej efektywnym. Co więcej, są użytecznym narzędziem w systemie budowania relacji między studentami (Dagiene, 2010).

Cohen $(1994$, s. 8) definiuje zadanie grupowe jako:

zadanie, wymagające zasobów (informacji, wiedzy, heurystycznych strategii rozwiązywania problemu, materiałów i umiejętności), których nie posiada żadna pojedyncza jednostka, tak że jest mało prawdopodobne, że ktoś rozwiąże problem samodzielnie lub osiągnie cele określone w zadaniu bez minimalnego choćby wkładu innych osób.

Trzeba też zauważyć, że czas potrzebny na rozwiązanie zadania jest istotnym zasobem. Zadanie grupowe nie może zatem zostać ukończone przez pojedynczą osobę w rozsądnych ramach czasowych.

Panitz (1999) omówił różnice między kolaboracją a kooperacją w procesie uczenia się. Wskazał on, iż kolaboracja jest raczej filozofią osobista, podczas gdy kooperacja powinna być rozumiana jako sposób rozwijania interakcji personalnych. Kooperacja jest potrzebna, 
by konkretny cel został osiąnięty przez grupę. Dlatego też w badaniach konkursu 24HOURS autorzy niniejszego artykułu porównali pracę indywidualną do kooperacji (nie kolaboracji) jako techniki uczenia się. Praca nad otwartymi zadaniami odnosi się raczej do kolaboracji niż do kooperacji; twierdzi się, że kooperacja stosowana jest do znalezienia uznanych lub przewidywanych odpowiedzi na problemy określone przez nauczycieli. Środowisko uczenia się jest więc silniej kontrolowane przez nauczyciela niż w sytuacjach kolaboracyjnych. Zgodnie z wnioskami Panitza (1999) konkursy (takie jak konkurs 24HOURS opisany w tym artykule) odnoszą się częściej do kolaboracji niż do kooperacji.

Jeśli zgodzimy się, że rozwijanie kreatywności jest najbardziej pożądaną umiejętnością $\mathrm{w}$ trakcie konkursu, to powinno się ono znaleźć $w$ centrum uwagi organizatorów i członków jury. W rezultacie przewiduje się, że zwycięzcy konkursu są jednocześnie jego najbardziej kreatywnymi uczestnikami. Studenci skoncentrowani na kooperacji z innymi powinni być bardziej kreatywni niż ci skupieni na sobie, zainteresowani rozwijaniem kompetencji własnych lub wygraną. Jeśli zatem głównym celem jest wygrana, trzeba się spodziewać, że rozwój kreatywności uczestników będzie ograniczony. Doświadczenie i wiedza wydają się kluczowe, aby można było wygrać konkurs, w którym oczekuje się, że uczestnicy stworzą nowe rozwiązania danego problemu (Artiles, Wallace, 2014). Jednakże zarówno Austin (1990), jak i Artiles i Wallace (2014) zaznaczyli, że wybór konkursów jako narzędzi do rozwiązywania jakichkolwiek - zwłaszcza złożonych - problemów może być wyzwaniem.

\subsection{ROLA OPIEKUNA W KONKURSIE}

W ostatnich latach stosunek studentów do procesu uczenia się na poziomie akademickim uległ zmianie. Jednocześnie zmieniło się również to, jak postrzegają oni rolę kompetencji społecznych rozwijanych w trakcie nauki na uczelni. Według Zalecenia Parlamentu Europejskiego i Rady z dnia 18 grudnia 2006 r. w sprawie kompetencji kluczowych w procesie uczenia się przez całe życie (2006) kompetencje społeczne są:

związane z dobrem osobistym i społecznym, które wymaga świadomości, w jaki sposób można zapewnić sobie optymalny poziom zdrowia fizycznego i psychicznego, rozumianego również jako zasób danej osoby i jej rodziny oraz bezpośredniego otoczenia społecznego, a także wiedzy, w jaki sposób może się do tego przyczynić odpowiedni styl życia.

Tak zwane kompetencje miękkie, odnoszące się do efektywnego zarządzania czasem i odpowiedzialnościa, skutecznego działania w sytuacjach społecznych, komunikacji w grupie lub motywacji, wydają się nabierać coraz większego znaczenia (Heckman, Kautz, 2012; Martowska, 2014).

Ustalono, że praca w małych grupach stwarza najlepsze warunki do uczenia się kooperatywnego. Stymuluje ona wszystkich studentów w grupie do zachowań prospołecznych (bycie współpracującym i przyjacielskim), aktywnego uczenia się i komunikacji. Kooperacja między studentami, zwłaszcza gdy mają do czynienia ze złożonymi zagadnieniami, powinna być wspierana przez nauczyciela lub opiekuna. Taka pomoc jest również potrzebna, gdy grupa studentów jest heterogeniczna, np. jeśli reprezentuje różne dyscypliny nauki lub odmienne poziomy zaawansowania (Cohen, 1994). Intensywna praca grupowa zachodzi, kiedy studenci korzystają wzajemnie ze swojej wiedzy i umiejętności. Oznacza to, że ten rodzaj pracy jest nie tylko przydzieleniem zadań do wykonania pojedynczym osobom z pominięciem interakcji. Zainicjowanie jej pomiędzy studentami pracującymi $\mathrm{w}$ tym samym zespole jest wyzwaniem. Opiekunowie grup muszą zatem być świadomi konieczności ustalenia poziomu interakcji między studentami (Cohen, 1994). Biorąc pod uwagę delikatną psychikę studentów, konkursy jako narzędzia edukacyjne należy wykorzystywać z rozwagą; uczestniczący w nich studenci powinni raczej stawić czoła rozwiązywaniu problemów niż być konfrontowani z innymi studentami (Dagiene, 2010).

Jak wspomniano, kreatywność studencka silniej stymulowana jest współpracą niż pracą indywidualną lub rywalizacją. Zatem najcenniejsze elementy konkursu to te, które są ukierunkowane na rozwijanie współpracy między uczestnikami. Głównym celem konkursu 24HOURS było rozwijanie kreatywności uczestników i pobudzenie mechanizmów, które wzmacniają raczej współpracę niż rozwijanie indywidualizmu i rywalizację. Edukacyjna skuteczność konkursów zależy od tego, czy opiekun potrafi wyjaśnić jego zasady oraz korzyści płynące ze współpracy i kreatywności. Dlatego też odpowiedzialność za promowanie kooperacji oraz kreatywności podczas konkursu powinna spoczywać zarówno na opiekunach, jak i na zespołach studenckich. W omawianym studium przypadku konkurs został oparty na nauczaniu metodą rozwiązywania problemów w turystycznej edukacji uniwersyteckiej. Zgodnie z powyższą dyskusją oznacza to, że badany konkurs 24HOURS powinien być przykładem techniki kolaboratywnego uczenia się, stosowanej w nauczaniu metodą rozwiązywania problemów. W związku z powyższym autorzy artykułu stawiają następujące pytanie badawcze: Czy opiekunowie grup studenckich biorących udział w konkursie są odpowiedzialni za uruchomienie mechanizmów ukierunkowanych na kooperację i kreatywność studentów w trakcie konkursu? 


\section{METODYKA BADAŃ}

\subsection{KONKURS 24HOURS JAKO STUDIUM PRZYPADKU}

Konkurs 24HOURS został zorganizowany w Łodzi (Polska) 14 listopada 2014 r. przez dwie instytucje akademickie: Uniwersytet Łódzki (Polska) i Lillehammer University College (Norwegia), obecnie noszący nazwę Inland Norway University of Applied Sciences. Ideą przewodnią było zaimplementowanie norweskiego konkursu edukacyjnego 24HOURS w Polsce (Schedule project..., 2015). Zespołom studenckim (jeden opiekun i czworo studentów) biorącym udział w konkursie dano 24 godziny na wybór najlepszej strategii rozwoju turystyki MICE ${ }^{2}$ w Łódzkim Obszarze Metropolitalnym (Polska). Konkurs 24HOURS otrzymał dofinansowanie ze środków Norweskiego Mechanizmu Finansowego oraz Mechanizmu Finansowego Europejskiego Obszaru Gospodarczego. Oficjalnym językiem wydarzenia był język angielski.

Organizatorzy konkursu 24HOURS zdecydowali się zaprosić zespoły studenckie - zamiast indywidualnych studentów - jako reprezentantów różnych instytucji akademickich. Decyzję taką podjęto ze względu na fakt, że środowisko kooperatywne stwarza lepsze warunki do nauki niż kompetytywne (Prince, 2004). Otrzymano i przyjęto zgłoszenia od siedmiu zespołów, reprezentujących sześć instytucji akademickich: Lillehammer University College, Politechnikę Łódzka, Uniwersytet Ekonomiczny w Poznaniu, Uniwersytet Łódzki, Szkołę Główną Turystyki i Hotelarstwa w Warszawie oraz Uniwersytet Przyrodniczy we Wrocławiu.

Organizatorzy konkursu 24HOURS starali się zachować równowagę płci w obrębie zespołów. Cohen (1994) twierdziła, że zespoły składające się z równej liczby kobiet i mężczyzn mogą wyeliminować negatywny wpływ struktury płci na efektywność pracy grupowej. Każdy zespół uczestniczący w konkursie musiał być wspierany od strony merytorycznej przez opiekuna. Celem takiego działania było zniwelowanie negatywnych skutków nieposiadania przez grupy opiekuna doświadczonego w nauczaniu metodą rozwiązywaniu problemów, które w tym przypadku wiązało się również z własnym tempem i zarządzaniem pracą przez grupę (Prince, 2004). Rekomendowanymi kandydatami na opiekunów byli doktoranci. Artiles i Wallace (2014) uważają warsztaty i tutoriale za najbardziej wartościowe części programu konkursu. W związku z powyższym konkurs 24HOURS został wzbogacony tematyczną wycieczką po mieście z przewodnikiem. Dodatkowo organizatorzy zapewnili prezentację na temat planowania typu post-it. Po zakończeniu konkursu, podczas tygodniowej wizyty w Lillehammer, zwycięski zespół zaprezentował wypracowane przez siebie podczas zawodów rozwiązanie. Omówiono abstrakt i szczegóły przyszłego artykułu naukowego poświęconego osiągnięciom zwycięskiego zespołu.

Ważnym narzędziem konkursu 24HOURS były strona internetowa oraz media społecznościowe (Twitter i Facebook). Strona internetowa stanowiła dla uczestników podstawowe źródło informacji, które udostępniono studentom przed konkursem. Wcześniej opiekunowie przygotowali prezentacje dla wszystkich uczestników na temat, którego dotyczył konkurs, a zespoły musiały porównać swoją wiedzę z wiedzą wszystkich innych uczestników. Podobnie jak w badaniach Sigali (2002) ideą konkursu 24HOURS było wykorzystanie wiedzy, a nie jej internalizacja czy reprodukcja.

Zadanie do rozwiązania podczas konkursu 24 HOURS zostało określone przez jury i publicznie ogłoszone na początku zmagań. Jury składało się z osób reprezentujących organizatorów, jak i z ekspertów zewnętrznych. Zadanie polegało na przygotowaniu Strategii rozwoju turystyki MICE w Łódzkim Obszarze Metropolitalnym 2020+. Każdy zespół studencki został poproszony o zamieszczenie rezultatów swojej pracy w otrzymanym od organizatorów szablonie prezentacji i dostarczenie tego materiału do jury. Następnie zespoły uczestniczace $\mathrm{w}$ konkursie prezentowały przed publicznością opracowane przez siebie strategie. Każdy zespół miał siedem minut na prezentację, którą jury oceniało według dziewięciu kryteriów, takich jak: wartość zaproponowanego rozwiązania; uwzględnione warunki i ich ocena, diagnoza strategiczna; określenie wizji/misji oraz celów strategicznych; działania strategiczne i odpowiedzialne instytucje / główni aktorzy; ocena ryzyka; plan wdrożenia strategii; podsumowanie; kompletność rozwiązania; ogólne wrażenie.

Konkurs 24HOURS został przeprowadzony nie tylko jako wydarzenie edukacyjne, ale również jako studium przypadku w badaniach nad turystyczną edukacją uniwersytecką. Idea połączenia stosowania metod edukacyjnych z badaniem ich efektywności była już wykorzystana $w$ innych projektach:

- CHERMUG (Continuing/Higher Education in Research Methods Using Games), który został opracowany, aby zweryfikować możliwość wdrażania gier cyfrowych do kształcenia ustawicznego (Johnston, Boyle, MacArthur, Manion, 2013);

- VR-ENGAGE (A Virtual Reality Education Game) w zakresie szkolnej edukacji geograficznej (Virvou, Katsionis, 2008);

- Play the Learning Game, którego celem było stworzenie międzynarodowej sieci dydaktyków zainteresowanych innowacyjnym i efektywnym zastosowaniem gier cyfrowych (Pauschenwein, Goldgruber, Sfiri, 2013);

- EPINOISI (Digital Game Based Learning, Computer. Games, Intellectual Disability, Learning Games Design), 
przeprowadzony w celu przedyskutowania potencjału i ograniczeń stosowania gier cyfrowych w nauczaniu studentów z lekkim upośledzeniem intelektualnym (Saridaki, Gouscos, Meimaris, 2006).

\subsection{ZBIERANIE DANYCH}

Aby ocenić skuteczność konkursu 24HOURS, zastosowano trzy metody zbierania danych. Najpierw wszystkim uczestnikom konkursu rozdano krótki, pisemny kwestionariusz. Ankieta została przeprowadzona tuż przed ostateczną decyzją jury i ceremonią przyznania nagród. Zawierała ona pytania otwarte i zamknięte, mające na celu ocenę ogólnej opinii uczestników na temat konkursu 24HOURS, jego aspektów organizacyjnych, głównego motywu udziału oraz wyjątkowości wydarzenia. Otrzymano 35 wypełnionych kwestionariuszy (100\% próby badawczej).

Ponadto przeprowadzono indywidualne wywiady pogłębione, aby lepiej zrozumieć opinię uczestników na temat konkursu. Warto podkreślić, że są one bardziej interaktywną metodą gromadzenia informacji niż wywiady kwestionariuszowe (Savenye, Robinson, 2005). Wywiady zostały przeprowadzone 6 marca 2015 r. (pod koniec wizyty studyjnej w Lillehammer, w której udział był jednocześnie nagrodą dla zwycięskiej grupy) z opiekunami (T1 i T2) oraz z ośmioma studentami (S1-S8), reprezentującymi dwie drużyny uczestniczące w konkursie 24HOURS. Aby zrealizować badanie, przygotowano wcześniej scenariusz wywiadu z gotowym zestawem pytań szczegółowych. Przeciętny wywiad trwał 18 minut, a te przeprowadzane $z$ opiekunami były dłuższe. Uczestnicy byli pytani, czy ich kompetencje społeczne, wiedza i umiejętności organizacyjne uległy poprawie lub rozwinęły się w trakcie konkursu 24HOURS. Oceniano także, jakie ogólne wrażenie wywarł on na uczestnikach.

Autorzy skorzystali również z kwestionariusza internetowego, aby ocenić stosunek uczestników do najważniejszych aspektów społecznych konkursu 24HOURS, tj. pracy indywidualnej, rywalizacji i kooperacji. Podobnie jak indywidualne wywiady pogłębione, ankieta online została przeprowadzona kilka miesięcy po konkursie.

\subsection{METODY ANALIZY}

Powszechnie stosowane ramy oceny narzędzi edukacyjnych powinny się odnosić do trzech elementów: studenta, nauczyciela i zasobów. Ponadto należałoby uwzględnić cztery główne wymiary oceny narzędzi edukacyjnych: miejsce, gdzie narzędzie jest zastosowane; uczeń lub grupa uczniów; miejsce (istniejące lub symulowane) wykorzystane do wprowadzenia problemu, który ma być rozwiązany; i wreszcie - krytyczna refleksja nad procesem uczenia się (de Freitas, Oliver, 2006). Należy ocenić zarówno użyteczność narzędzia, jak i odczucia, jakie ono wzbudza. Z jednej strony w celach edukacyjnych powinny być wykorzystywane wyłącznie lubiane narzędzia. Z drugiej zaś tylko narzędzia użyteczne mogą uczynić proces uczenia relatywnie efektywniejszym (Virvou, Katsionis, 2008).

Zebrane dane jakościowe znacznie się różniły od siebie, zarówno przy porównaniu członków zespołu, jak i całych zespołów. Po przełożeniu tych danych na tekst zastosowano techniki porządkujące w celu zinterpretowania dużej ilości danych (Angrosino, 2008; Gibbs, 2008; Kvale, 2008). Wyniki jakościowe wykorzystano do określenia i zweryfikowania następujących pytań badawczych:

1. Które kompetencje społeczne studentów uległy poprawie lub rozwinęły się podczas konkursu 24HOURS?;

2. Czy konkurs umożliwił studentom poprawienie i rozwinięcie ich wiedzy?;

3. Jakie funkcje pełnili członkowie zespołu w trakcie konkursu?;

4. Jaki był indywidualny odbiór konkursu?

Prince (2004) twierdził, że często trudno jest zmierzyć wiele ważnych efektów kształcenia, szczególnie w przypadku, kiedy chodzi o pomiar efektów nauczania metodą rozwiązywania problemów. Dlatego też przeprowadzono ankietę online dotyczącą społecznych aspektów konkursu 24HOURS, aby ocenić stosunek studentów do pracy w trakcie konkursu, potencjalne kompetencje, które rozwinęli, oraz ogólne wrażenia związane z uczestnictwem w zawodach. Wyniki ankiety zostały przeanalizowane z wykorzystaniem grupowania metodą $k$-średnich i zaprezentowane za pomocą wykresów trójkątnych.

Grupowanie metodą $k$-średnich zastosowano dwukrotnie, by zidentyfikować homogeniczne grupy studentów w odniesieniu do odrębnie badanych zjawisk:

- trzech typów umiejętności i kompetencji, które zostały wskazane przez uczestników jako najważniejsze efekty konkursu 24HOURS - wiedzy, kreatywności i kompetencji społecznych;

- trzech najważniejszych typów relacji społecznych wytworzonych pomiędzy uczestnikami konkursu 24HOURS - kooperacji, rywalizacji i koncentracji na pracy indywidualnej.

Grupowanie metodą k-średnich, jako jeden z algorytmów dostępnych $\mathrm{w}$ analizie skupień, prowadzi do wyodrębniania grup podobnych obiektów (klastrów). Metoda ta dopuszcza różne scenariusze grupowania i polega na przesuwaniu obiektów z jednej grupy do innej do chwili, kiedy wariancje w klastrach i pomiędzy nimi zostaną zoptymalizowane (Kanungo i in., 2002). Aby zaprezentować wyniki opisanej analizy, opracowano wykresy trójkątne osobno dla trzech różnych typów badanych umiejętności i kompetencji oraz dla trzech 
różnych rodzajów badanych relacji społecznych. Trzeba wyjaśnić, że wykres trójkątny pokazuje proporcje trzech zmiennych, które sumują się do stałej wartości, zatem może on być wykorzystywany do prezentacji zjawisk o trzyczęściowej strukturze. Graficznie przedstawia on proporcje trzech zmiennych jako pozycji w trójkącie równobocznym (Korycka-Skorupa, 2007; Runge, 2006).

\section{WYNIKII DYSKUSJA}

\subsection{OGÓLNA OPINIA O KONKURSIE 24HOURS}

Ogólna opinia o konkursie, wynikająca z zastosowania wszystkich metod zbierania danych, była pozytywna (rys. 3). Czynniki, takie jak: organizatorzy, wolontariusze oraz wycieczka po mieście (która również była częścią całego wydarzenia), zostały ocenione bardzo wysoko. Warto podkreślić, że czynniki ludzkie uznano za najlepszą część wydarzenia. Jednakże udostępniona infrastruktura informatyczna i komunikacyjna, jak również wyżywienie otrzymały znacznie niższe noty. Można przypuszczać, że współczesne oczekiwania studentów co do warunków nauki i pracy są bardzo wysokie. Trzeba podkreślić, iż uczestnicy konkursu skupieni na idei wydarzenia, a nie na nagrodzie, ocenili wszystkie czynniki ludzkie wyżej niż inni, bardziej materialistycznie nastawieni studenci. Znacznie mniej zależało im na zapewnionym przez organizatorów wyżywieniu czy napojach. Byli oni jednak niezwykle uwrażliwieni na

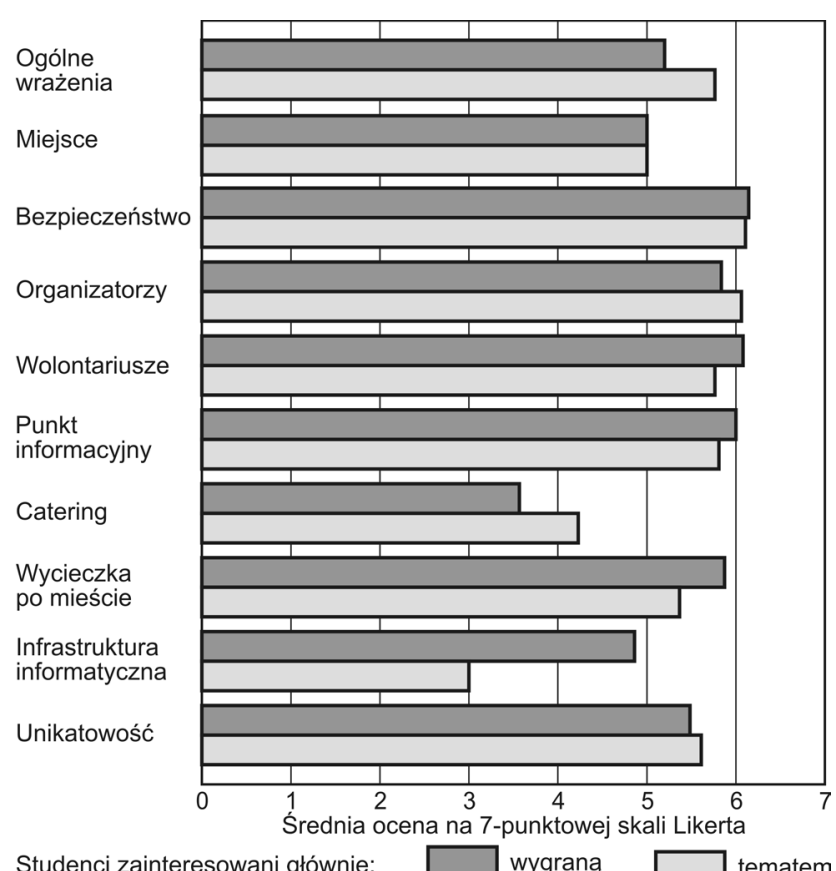

Rysunek 3. Ocena konkursu 24HOURS przez uczestników a ich zainteresowanie wygraną Źródło: opracowanie własne na podstawie ankiety papierowej kwestie jakości infrastruktury informatycznej i komunikacyjnej udostępnionej przez organizatorów, uznanej przez studentów za jeden z najważniejszych zasobów, niezbędnych do osiągnięcia oczekiwanych rezultatów.

Program konkursu został uznany za główny czynnik decydujący o ogólnym wrażeniu, jakie na uczestnikach wywarło wydarzenie. Odnośnie do tego aspektu warto przytoczyć niektóre opinie studentów, np. (S5): „To był naprawdę dobry konkurs, ale zbyt długo trwał; 24 godziny były dla nas naprawdę męczące". Inny student zauważył (S1):

Około 5 rano byłem tak zmęczony, że usnąłem na krześle i... wiedzieliśmy, że mamy jeszcze dwie godziny i projekt musi być gotowy, i... poczuliśmy się... ja się poczułem trochę sfrustrowany. Potrzebuję snu, potrzebuję jedzenia i... kiedy brakuje łazienki, trudno jest się skupić, skoncentrować.

\subsection{STYMULOWANIE KREATYWNOŚCI POPRZEZ KONKURS 24HOURS}

Gdy pod dyskusję poddawane są umiejętności i kompetencje studentów, kreatywność powinna byś skonfrontowana z umiejętnościami społecznymi i poznawczymi. Studentów poproszono, by wskazali te umiejętności i kompetencje, które zostały najbardziej wzmocnione przez uczestnictwo w konkursie 24HOURS (rys. 4). Trzeba podkreślić, że indywidualna wiedza była uznawana przez większość studentów za podstawową umiejętność rozwijaną podczas konkursu. Tylko jedna grupa uczestników (reprezentowana przez trójkąty na rys. 4) uważała kreatywność za najważniejszą umiejętność.

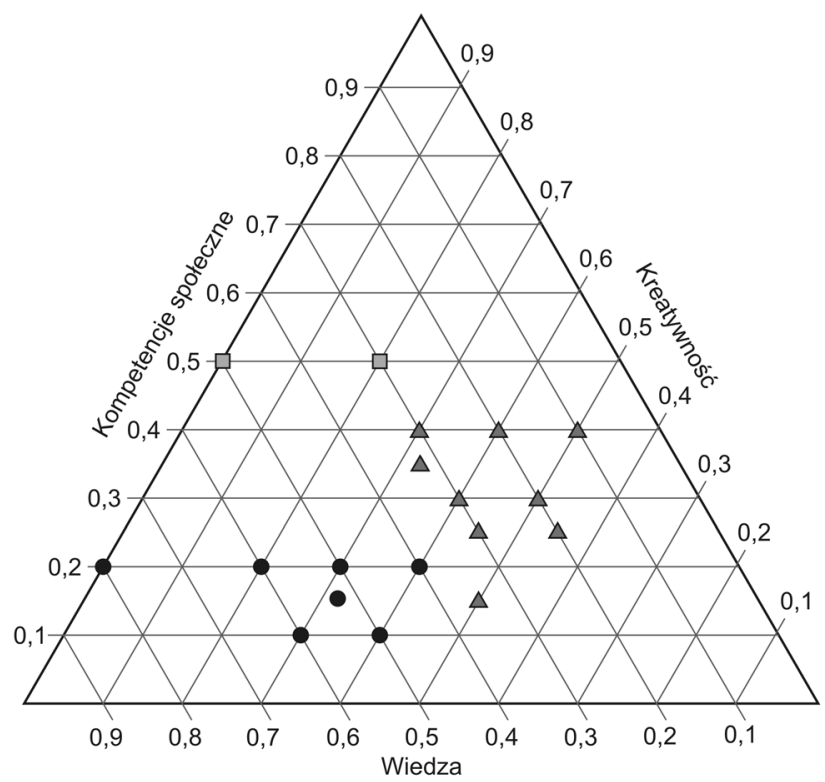

Rysunek 4. Umiejętności i kompetencje wskazane przez uczestników konkursu 24HOURS jako najlepiej rozwijane podczas wydarzenia Źródło: opracowanie własne na podstawie ankiety online 
Co więcej, niektóre grupy zauważyły, że kreatywność wzrastała podczas konkursu bardziej poprzez rozwijanie kompetencji społecznych niż indywidualnej wiedzy.

Informacje zawarte $\mathrm{w}$ ankietach przeprowadzonych online były zgodne z wynikami wywiadów pogłębionych. Studenci argumentowali, że wiedza stanowiła główną umiejętność rozwijaną podczas konkursu 24HOURS. Przykładowo S1 powiedział:

Nie wiedziałem nic o turystyce MICE. Nie wiedziałem, co oznacza to słowo. I... wiele się nauczyłem na ten temat, o turystyce MICE... Nauczyłem się wielu nowych terminów i... kiedy wróciłem, skorzystałem na moim egzaminie z wielu informacji, które zdobyłem w Polsce.

Podobnie inny student (S6) powiedział, że:

Dowiedziałem się wiele o strategii - jak ją budować, jaka jest jej struktura, a więc misja, wizja i co powinniśmy robić [...]. Oczywiście mieliśmy zajęcia o tym na naszej uczelni, ale było to obowiązkowe i - szczerze mówiąc - nie lubimy tego przedmiotu.

Znalazły się jednak również odmienne opinie. Uczestnicy pisali, że wzrosły ich wiedza i umiejętności społeczne potrzebne do pracy grupowej podczas konkursu. Dla przykładu, jeden student stwierdził (S1):

Zdobyłem nową wiedzę na temat turystyki MICE i prawdopodobnie o pracy pod presją z innymi ludźmi. Postrzegam moją rolę trochę wyraźniej, jako kogoś, kto wpada na dobre pomysły i rozwija je. Ale być może nie jestem idealną osobą do pisania tekstu. Mogę być osobą z pomysłami i rozwiązaniami. A ktoś inny byłby dziewczyną lub chłopakiem odpowiedzialnym za pisanie.

Inny student (S3) zauważył:

Wszystko dzieliliśmy po równo. Nie wiem, czy to dobrze czy źle. Dowiedzieliśmy się więcej o tym, jak pracować w zespole. Dla niektórych bycie liderem jest po prostu bardziej naturalne niż dla innych. Myślę, że jako zespół bardzo dobrze sobie poradziliśmy.

Na temat okazji do bycia kreatywnym studenci wypowiadali się na przykład w następujący sposób (S6): "Odbyliśmy burzę mózgów i to było niesamowite, że było tak późno, a my mieliśmy na stole analizę SWOT. Mieliśmy mnóstwo pomysłów o tak późnej porze. To było dla nas wspaniałe. Dobrze się bawiliśmy. Zrobiliśmy to i wygraliśmy".

Twierdzi się, że kreatywność i umiejętności kognitywne są pozytywnie skorelowane z otwartością (Liang, Lin, 2015). Trzeba zauważyć, że podczas wywiadów tylko najbardziej ekstrawertyczni studenci nie mieli problemów z określeniem efektów swoich kreatywnych zachowań, np. (S1): „Wpadłem na pomysł na stronę pod tytułem «Meet in Lodz», ponieważ przeszukiwaliśmy sieć, by znaleźć jakieś informacje, ale nie ma nic po angielsku, więc było nam bardzo trudno dowiedzieć się czegokolwiek". Jeden ze studentów wskazał nawet introwertyczność jako znaczącą słabość innych osób uczestniczących w konkursie (S1):

Polacy nie są tak otwarci jak Norwegowie. Od razu zauważyłem, że kiedy tam dotarliśmy, byliśmy jak... z Norwegii. Ale Polacy nie są tacy jak my. Więc było... nie było łatwo nawiązać kontakt z kimkolwiek [...]. Zabrało to trochę czasu, żeby się otworzyli na nas. Tak więc myślę, że polscy studenci są trochę zamknięci. I niełatwo nawiązać z nimi kontakt. Mogliby być trochę bardziej otwarci, tak jak my, Norwegowie. Wtedy prawdopodobnie zawarlibyśmy znacznie więcej przyjaźni.

Relacje między studentami, które rozwinęły się podczas konkursu 24HOURS, zostały podzielone na trzy grupy: koncentracja na pracy indywidualnej (brak interakcji między studentami), rywalizacja i współpraca (rys. 5). Większość studentów chętnie skupiała się równolegle na współpracy i pracy indywidualnej. Jednakże jeśli chodzi o zasady konkursu, praca zespołowa była narzucona przez organizatorów, zatem studenci mogli współzawodniczyć i współpracować w tym samym czasie (zob. studenci reprezentowani przez kwadraty na rys. 5).

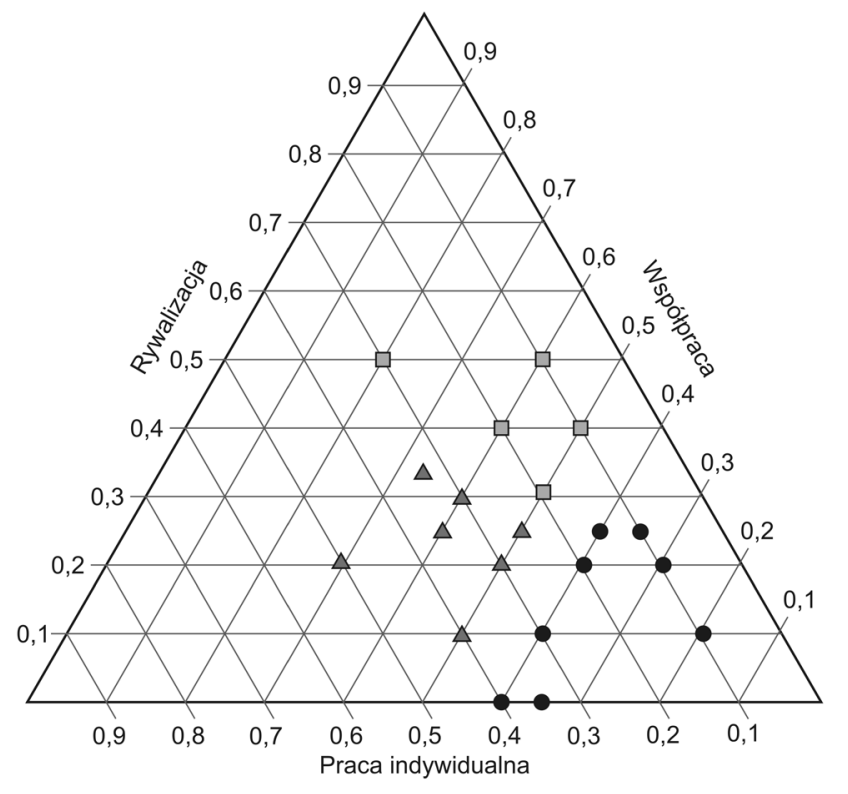

Klasa 1: praca indywidualna $=0,200$, współpraca $=0,655$, rywalizacja $=0,145$ $\triangle$ Klasa 2: praca indywidualna $=0,333$, współpraca $=0,443$, rywalizacja $=0,223$ $\square$ Klasa 3: praca indywidualna $=0,178$, współpraca $=0,411$, rywalizacja $=0,411$

Rysunek 5. Postawy społeczne wskazane przez uczestników konkursu 24HOURS jako najlepiej rozwijane podczas wydarzenia Źródło: opracowanie własne na podstawie ankiety online

Trzeba podkreślić, że studenci uznali współpracę za najważniejszy element pracy zespołu, np. S7 powiedział: „Przede wszystkim praca zespołowa - to klucz do tworzenia całej strategii dla Łodzi. Ponieważ mieliśmy tylko 24 godziny, nie mogłem przygotować 
całej strategii sam”. T2 i S8 również zwrócili uwagę na tę kwestię: „Wszyscy zdecydowaliśmy się wziąć część pracy na siebie". Jednak współpraca między zespołami nie była czymś oczywistym $\mathrm{w}$ trakcie konkursu. $Z$ jednej strony, gdy członkowie zespołu kooperowali, nie było idealnych warunków do rozwijania kreatywności. $\mathrm{Z}$ drugiej strony, studenci uważali rywalizację między zespołami za istotna, np. (S8): „Jeśli by nie było rywalizacji, nie byłoby takiej zabawy. Ponieważ nie musimy niczego dokańczać, możemy po prostu powiedzieć: «W porządku, to bez znaczenia». Ale kiedy wiedzieliśmy, że rywalizujemy z innymi zespołami, stawało się to ważne". Podczas gdy nadrzędnym celem studentów uczestniczących w konkursie była współpraca (ale tylko z członkami własnego zespołu) i rywalizacja (by wygrać), jako główna umiejętność rozwijana w trakcie wydarzenia została wskazana indywidualna wiedza, a nie kreatywność.

\subsection{ROLA OPIEKUNÓW W KONKURSIE 24HOURS}

Rola opiekuna w grupie studentów może być rozumiana jako pełnienie funkcji przewodnika w planowaniu pracy projektowej. Ma on uważnie pilotować projekt, zwłaszcza właściwie oszacować czas potrzebny na zrealizowanie celu (Roisin, Fitzmaurice, 2005). Głównym zadaniem opiekuna powinno być pomaganie grupie, zwłaszcza w sytuacji kiedy studenci nie mogą znaleźć odpowiedniego sposobu rozwiązania problemów przy opracowywaniu projektu (Woltering, Herrler, Spitzer, Spreckelsen, 2009). Podczas konkursu 24HOURS rola opiekuna w grupie okazała się problematyczna. Wywiady pogłębione wykazały, że opiekunowie byli niepewni, jakie są oczekiwania związane $\mathrm{z}$ ich zaangażowaniem $\mathrm{w}$ pracę grupy.

W przebadanej zwycięskiej grupie zakres odpowiedzialności opiekuna był bardzo szeroki; pełnił on funkcję naturalnego przywódcy i wykonał dużą część pracy. Zostało to potwierdzone przez studentów, np. (S5): , ,[...] ponieważ ma ona dużą wiedzę. I zna lepiej angielski niż my". Inny uczestnik zauważył (S6): „Robiła wiele rzeczy. Korzystała z informacji ze swoich studiów [...]. To było dla nas bardzo przydatne". W odniesieniu do efektów edukacyjnych konkursu 24HOURS, nieokreślona rola opiekuna powinna być uznana za główne ograniczenie. Wspomaganie nauczyciela przez studentów było postrzegane jako najlepsza strategia, by wygrać. Jednakże stało to w sprzeczności z głównym celem edukacyjnym, zgodnie z którym to opiekun wspomaga studentów.

Opiekun w innej badanej grupie odgrywał zupełnie odmienną rolę. Jak zauważył jeden ze studentów (S1): "powiedział, że może nam pomóc, ale nie może dać nam odpowiedzi i nie może... nie może za nas zrobić prezentacji". W opinii wspomnianego opiekuna (T1), liderem zespołu była jedna ze studentek, która „mówiła im, co robić. Ona powiedziała, co musi być zrobione. Przejrzała zadania i przydzieliła różne poszczególnym osobom". Jednocześnie studenci zauważyli, że opiekun nie wykonywał żadnych zadań w projekcie (S2): „Nie robił za dużo. Tylko odpowiadał na pytania, jeśli je zadawaliśmy. Wszystko robiliśmy sami".

Gdy cele edukacyjne konkursu są stawiane na pierwszym planie, rola opiekuna powinna być ściśle określona. Tak jak to sformułowano w pytaniu badawczym, opiekunowie są odpowiedzialni za uruchomienie mechanizmów umożliwiających zarówno współpracę, jak i kreatywność studentów w trakcie konkursu. Jeśli jednak obowiązki opiekuna nie zostaną jasno opisane, istnieje ryzyko, że kreatywność będzie się rozwijała raczej poprzez wiedzę indywidualną i rywalizację. To nie jest tak efektywne, jak mogłoby być, gdyby kreatywność stymulowana była poprzez kompetencje społeczne i kooperację. Ta część badania ukazała jednocześnie największą słabość konkursu 24HOURS.

\section{WNIOSKI}

Kreatywność studentów kierunków turystycznych stymulowana była przez konkurs, w którym kilka zespołów wymyślało różnorodne innowacyjne rozwiązania faktycznie istniejącego problemu z zakresu przemysłu turystycznego. Studenci uczestniczący w wydarzeniu, co sami potwierdzili, byli pozytywnie nastawieni do konkursu 24HOURS, który wyraźnie łączył teorię z praktyka, tak jak to przedstawił Fidgeon (2010), rozwijając programy nauczania poprzez równoważenie celów zawodowych i akademickich. Od studentów kierunków turystycznych oczekiwano, że będą się oni odwoływać do swojej wiedzy akademickiej, aby rozpoznać i rozwiązać rzeczywisty problem z ich dziedziny studiów. Kreatywność nie była jednakże głównym aspektem uczenia się stymulowanego przez konkurs. Uczestnicy uważali, że udział w tych zawodach przede wszystkim poszerzył ich wiedzę indywidualną na temat przemysłu turystycznego i zasad jego działania, jak również że podnieśli swoje umiejętności społeczne, potrzebne, by pracować w zespole. Ponadto współpraca z członkami własnego zespołu rozwijała się lepiej niż z pozostałymi uczestnikami konkursu.

Biorąc pod uwagę argumentację Dale'a i Robinsona (2001), w dyskusji na temat efektywności konkursu jako narzędzia edukacyjnego na studiach turystycznych powinna nastąpić konfrontacja z osobami odpowiedzialnymi za programy nauczania. Niemal połowa polskich studentów uczestniczących w konkursie 24HOURS została przyjęta z nieturystycznych programów studiów. Pokazuje to, że złożone problemy przemysłu turystycznego mogą być skutecznie 
rozwiązywane nie tylko przez specjalistów z dziedziny turystyki. Co ważniejsze, badanie wykazało dużą rolę konkursów w stymulowaniu uczenia się o branżach takich jak turystyczna oraz w pobudzaniu kreatywności w celu znalezienia „zwycięskiego rozwiązania”. Co więcej, jak twierdzą Artiles i Wallace (2014), tworzenie zespołów interdyscyplinarnych w konkursie jest skutecznym sposobem zaznajamiania osób biorących w nim udział z innymi dyscyplinami. Praca ze studentami innych kierunków jest o wiele bardziej efektywna niż zmuszanie uczestników, by brali udział w wykładach prowadzonych przez zawodowców reprezentujących inne dziedziny. Nie stwierdzono jednak kooperacji między zespołami, zatem wspomniany powyżej pozytywny skutek połączenia interdyscyplinarności i kooperacji nie wystąpił podczas konkursu 24HOURS.

Odkrycia Johnstona, Boyle, MacArthura i Maniona (2013) są ważne dla implementacji konkursów w uniwersyteckiej edukacji turystycznej. Konkursy powinny angażować studentów i wzbudzać ich zainteresowanie bieżącymi problemami naukowymi. Należy zachęcać studentów do formułowania jasnych pytań badawczych, formułowania i walidacji projektu oraz do nauki stosowania metod jakościowych i ilościowych. Studenci powinni być kreatywni. Wszystkie wspomniane powyżej wyzwania należy brać pod uwagę, gdy definiowana jest rola opiekunów studentów podczas konkursu. Tak jak to zostało podkreślone w pytaniu badawczym, opiekunowie są odpowiedzialni za uruchomienie mechanizmów stymulujących kooperację i kreatywność studentów.

Austin (1990) sugeruje, że powinno się rozważyć kilka czynników związanych z konkursami jako narzędziami edukacyjnymi. Po pierwsze w kulturach amerykanistycznych rywalizacja jest bardziej fetyszem niż naturalną częścią ludzkiej natury. Po drugie rywalizacja niekoniecznie motywuje ludzi do maksymalnego wysiłku, ponieważ może ona nie zależeć od kompetencji. Po trzecie pewność siebie nie jest wyraźnym efektem uczestnictwa w konkursie. Należy zatem stwierdzić, że konkurs 24HOURS nie okazał się w pełni udanym środowiskiem uczenia się. Co więcej, pragnienie wygranej zachęca raczej do zdobywania nowej wiedzy w dziedzinie turystyki niż do kreatywności.

\section{PRZYPISY}

\footnotetext{
${ }^{1}$ Badanie zostało dofinansowane ze środków Norweskiego Mechanizmu Finansowego oraz Mechanizmu Finansowego Europejskiego Obszaru Gospodarczego, w ramach umowy nr FSS/2013/IIC/W/0008/U/0023 pomiędzy Fundacją Rozwoju Systemu Edukacji (odpowiedzialną za Fundusz Stypendialny i Szkoleniowy) a Uniwersytetem Łódzkim.
}

${ }^{2}$ MICE to akronim utworzony ze słów meetings (spotkania), incentives (korzyści/zachęta), conventions (konwencje) oraz exhibitions (wystawy). Turystyka typu MICE jest związana ze wszystkimi wspomnianymi formami podróży służbowych (Sylla, Chruściński, Drużyńska, Płóciennik, Osak, 2015).

\section{BIBLIOGRAFIA}

Angrosino, M. (2008). Doing ethnographic and observational research. London: SAGE. DOI: https://doi.org/10.4135/9781849208932

Artiles, J.A., Wallace, D.R. (2014). Methods for innovation: Observations from the Education DesignShop. FabLearn 2014, Conference on Creativity and Fabrication in Education, 25-26 października, Stanford University, USA.

Austin, J.R. (1990). Competition - is music education the loser? Music Educators Journal, 76 (6), 21-25. DOI: https://doi. org $/ 10.2307 / 3400964$

Barkathunnisha, A.B., Lee, D., Price, A. (2017). Transcending towards a spirituality-based platform in tourism higher education: a contemplation of the pedagogical implications. Journal of Hospitality, Leisure, Sport and Tourism Education, 21, 174-184. DOI: https://doi.org/10.1016/j.jhlste.2016.11.003

Boyle, E., Rosmalen, P. Van, Macarthur, E., Connolly, T., Hainey, T., Johnston, B., Ger, P.M., Fernández, B., Kärki, A., Pennanen, T., Manea, M., Starr, K. (2012). Cognitive task analysis (CTA) in the continuing/higher education methods using games (CHERMUG) project. W: F. Patrick (red.), Proceedings of the European Conference on Games Based Learning (s. 63-72). Sonning Common: Academic Publishing International Limited.

Cohen, E.G. (1994). Restructuring the classroom: Conditions for productive small groups. Review of Educational Research, 64 (1), 1-35. DOI: https://doi.org/10.3102/00346543064001001

Dagiene, V. (2010). Sustaining informatics education by contests. Lecture Notes in Computer Science, 5941, 1-12. DOI: https://doi. org/10.1007/978-3-642-11376-5_1

Dagiene, V., Skupiene, J. (2004). Learning by competitions: Olympiads in informatics as a tool for training high-grade skills in programming. W: T. Boyle, P. Oriogun, A. Pakstas (red.), $2^{\text {nd }}$ International Conference on Information Technology: Research and Education (s. 79-83). London: IEEE. DOI: https://doi. org/10.1109/ITRE.2004.1393650

Dale, C., Robinson, N. (2001). The theming of tourism education: A three-domain approach. International Journal of Contemporary Hospitality Management, 13 (1), 30-35. DOI: https://doi. org/10.1108/09596110110365616

Fidgeon, P.R. (2010). Tourism education and curriculum design: A time for consolidation and review? Tourism Management, 31 (6), 699-723. DOI: https://doi.org/10.1016/j.tourman.2010.05.019

de Freitas, S., Oliver, M. (2006). How can exploratory learning with games and simulations within the curriculum be most effectively evaluated? Computers and Education, 46 (3), 249-264. DOI: https://doi.org/10.1016/j.compedu.2005.11.007

Gibbs, G. (2008). Analysing qualitative data. London: SAGE.

Heckman, J., Kautz, T. (2012). Hard evidence on soft skills. Labour Economics, 19 (4), 451-464. DOI: https://doi.org/10.1016/j. labeco.2012.05.014

Johnston, B., Boyle, L., MacArthur, E., Manion, B.F. (2013). The role of technology and digital gaming in nurse education. Nursing Standard, 27 (28), 35-38. DOI: https://doi.org/10.7748/ ns2013.03.27.28.35.s9612

Kanungo, T., Mount, D.M., Netanyahu, N.S., Piatko, C.D., Silverman, R., Wu, A.Y. (2002). An efficient k-means clustering 
algorithm: Analysis and implementation. IEEE Transactions of Pattern Analysis and Machine Intelligence, 24 (7), 881-892. DOI: https://doi.org/10.1109/TPAMI.2002.1017616

Korycka-Skorupa, J. (2007). Trójkąt Osanna jako forma prezentacji danych statystycznych i legenda map tematycznych. Polski Przeglad Kartograficzny, 39, 340-353.

Kvale, S. (2008). Doing interviews. London: SAGE. DOI: https:// doi.org/10.4135/9781849208963

Li, Y.Q., Liu, C.H. (2016). How to establish a creative atmosphere in tourism and hospitality education in the context of China. Journal of Hospitality, Leisure, Sport and Tourism Education, 18, 9-20. DOI: https://doi.org/10.1016/j.jhlste.2015.11.001

Liang, C., Lin, W.-S. (2015). The Interplay of creativity, imagination, personality traits, and academic performance. Imagination, Cognition and Personality, 34 (3), 270-290. DOI: https://doi. org/10.1177/0276236614568638

Martowska, K. (2014). Temperamental determinants of social competencies. Polish Psychological Bulletin, 45 (2), 128-133. DOI: https://doi.org/10.2478/ppb-2014-0017

Ndou, V., Mele, G., Del Vecchio, P. (2018). Entrepreneurship education in tourism: an investigation among European Universities. Journal of Hospitality, Leisure, Sport and Tourism Education, 25. DOI: https://doi.org/10.1016/j.jhlste.2018.10.003

Panitz, T. (1999). Collaborative versus cooperative learning: A comparison of the two concepts which will help us understand the underlying nature of interactive learning. Pobrane $\mathrm{z}$ : https:// pdfs.semanticscholar.org/82fe/2f093ed061f192e7e5fa44db 8588d0f48a9a.pdf?_ga=2.43844709.198895979.1585928208726482439.1585928208 (20.11.2019).

Paraskeva, F., Mysirlaki, S., Papagianni, A. (2010). Multiplayer online games as educational tools: Facing new challenges in learning. Computers and Education, 54 (2), 498-505. DOI: https:// doi.org/10.1016/j.compedu.2009.09.001

Pauschenwein, J., Goldgruber, E., Sfiri, A. (2013). The identification of the potential of game-based learning in vocational education within the context of the project 'Play the Learning Game'. International Journal of Emerging Technologies in Learning, 8 (1), 20-23. DOI: https://doi.org/http://dx.doi.org/10.3991/ ijet.v8i1.2359

Prince, M. (2004). Does active learning work? A review of the research. Journal of Engineering Education, 93, 223-231. DOI: https://doi.org/10.1002/j.2168-9830.2004.tb00809.x

Roisin, D., Fitzmaurice, M. (2005). Collaborative project-based learning and problem-based learning in higher education: A consideration of tutor and student role in learner-focused strategies. W: G. O’Neill, S. Moore, B. McMullin (red.), Emerging issues in the practice of University Learning and Teaching (s. 87-98). Dublin: AISHE/HEA. DOI: https://doi.org/10.1017/ CBO9781107415324.004
Rouzrokh, M., Muldoon, M., Torabian, P., Mair, H. (2017). The memory-work sessions: Exploring critical pedagogy in tourism. Journal of Hospitality, Leisure, Sport and Tourism Education, 21, 163-173. DOI: https://doi.org/10.1016/j.jhlste.2017.08.006

Runge, J. (2006). Metody badań w geografii społeczno-ekonomicznej. Elementy metodologii, wybrane narzędzia badawcze. Katowice: Wydawnictwo Uniwersytetu Śląskiego.

Saridaki, M., Gouscos, D., Meimaris, M. (2006). Digital games-based instructional design for students with special education needs: Practical findings and lessons learnt. The $4^{\text {th }}$ European Conference on Game Based Learning, 343-350.

Savenye, W.C., Robinson, R.S. (2005). Using qualitative research methods in higher education. Journal of Computing in Higher Education, 16 (2), 65-95. DOI: https://doi.org/10.1007/ BF02961475

Schedule project - significance of competition in higher education (2015). Pobrane z: http://schedule.edu.pl/ (12.11.2019).

Sigala, M. (2002). The evolution of internet pedagogy: Benefits for tourism and hospitality education. The Journal of Hospitality, Leisure, Sport and Tourism Education, 1 (2), 27-42. DOI: https:// doi.org/10.3794/johlste.12.4

Sigala, M., Baum, T. (2003). Trends and issues in tourism and hospitality higher education: Visioning the future. Tourism and Hospitality Research, 4 (4), 367-376. DOI: https://doi. org/10.1177/146735840300400409

Sylla, M., Chruściński, J., Drużyńska, P., Płóciennik, P., Osak, W. (2015). Analiza wybranych czynników rozwoju turystyki MICE na tle potencjału Łodzi. Turyzm/Tourism, 25 (2), 123-131.

Virvou, M., Katsionis, G. (2008). On the usability and likeability of virtual reality games for education: The case of VR-ENGAGE. Computers and Education, 50 (1), 154-178. DOI: https://doi. org/10.1016/j.compedu.2006.04.004

Woltering, V., Herrler, A., Spitzer, K., Spreckelsen, C. (2009). Blended learning positively affects students' satisfaction and the role of the tutor in the problem-based learning process: Results of a mixed-method evaluation. Advances in Health Sciences Education, 14 (725). DOI: https://doi.org/10.1007/ s10459-009-9154-6

Zalecenia Parlamentu Europejskiego i Rady z dnia 18 grudnia 2006 r. $w$ sprawie kompetencji kluczowych w procesie uczenia się przez całe życie (2006). Dziennik Urzędowy Unii Europejskiej, 2006/962/E. Pobrane z: https://eur-lex.europa.eu/legal-content/PL/TXT/PD F/?uri=CELEX:32006H0962\&from=EN (18.10.2019).

Artykuł wpłyną:

27 stycznia $2020 \mathrm{r}$

Zaakceptowano do druku: 6 maja $2020 \mathrm{r}$ 